\title{
ASSESSMENT OF SINGLE EXTRACTION METHODS FOR THE PREDICTION OF BIOAVAILABILITY OF METALS TO VIGNA UNGUICULATA L (BEANS) GROWN ON CRUDE OIL CONTAMINATED SOIL
}

\author{
${ }^{1 *}$ Olubodun, Stella O. and ${ }^{2}$ Eriyamremu, George, E. \\ ${ }^{1 *}$ Department of Science Laboratory Technology, Edo State Institute of Technology and \\ Management, Usen, Edo State, Nigeria; sabukadi@yahoo.com; +234 8023411948 \\ ${ }^{2}$ Department of Biochemistry, Faculty of Life Sciences, University of Benin, Nigeria;
}

\begin{abstract}
The bioavailability of toxic metals in the soils is increasingly an important issue as soil always becomes contaminated from various anthropogenic activities. Total concentrations of metals in the soils are generally poor indicators of metal toxicity because they exit in different solution and solid phase forms that can differ in terms of their bioavailability. As such, regulators are looking at bioavailability as an indicator of risk associated with metal contamination in soils. Since the bioavailability of metals, their biological uptake and eco-toxicological effect on soil biota can be understood better in terms of their biogeochemical forms, the study assessed the effect of crude oil applied at rates, 0, 2, 5, and 10\% on the fractional chemical forms and availability of some metals in soils from Usen, Edo State, with no known crude oil contamination and soil from a crude oil spill site in Ubeji, Delta State, Nigeria, using several techniques as a basis for predicting metal uptake by plants. Bean seeds were grown in the contaminated soil for 21days and the metal concentrations in the seedlings were compared with the total soil metal concentrations, bioavailable metal concentrations and EDTA-extractable metal concentrations.
\end{abstract}

Keywords: bioavailability, chemical forms, crude oil-contaminated soil, EDTA, metal concentrations,

\section{INTRODUCTION}

Soil as an important component of rural and urban environments is increasingly being exposed to changes resulting from both natural and anthropogenic sources. The anthropogenic sources have been attributed to the indiscriminate disposal and/or discharge of industry and mine waste or effluent (Ikhuoria and Uyammadu, 2000) and these activities have neither been regularized nor monitored (Sarkodie et al., 1997).

Crude oil is a liquid and contains complex mixtures of hydrocarbons, some organic materials and trace amounts of metals and heavy metals depending on its composition (Albers, 1995). The presence of heavy metals in the soil can be beneficial on the one hand in the normal growth of plants and living organisms. The heavy metals that are beneficial for normal growth of plants include iron, zinc, copper, etc. These heavy metals may be detrimental on the other hand in its toxicity associated with excess or the presence of heavy metals such as lead $(\mathrm{Pb})$, cadmium (Cd) and mercury $(\mathrm{Hg})$ that lack essential function in plants (Okoye and Okwute, 2014; Pourrut et. al., 2011). Nigerian crude oil contains some of these heavy metals that are non-biodegradable so they can accumulate in the ecosystem for a long time and cause toxic effects on the flora and fauna of both the terrestrial and aquatic environment (Ntiforo et. al., 2012; Obasi et al., 2013, Okoye and Okwute, 2014; Wu and Zhang, 2010).

Nigeria as an established crude oil nation produces a total of about 2.29 million barrels/day of medium and light crude oil, such as Bonny Light (Amund and Akangbou, 1993). Since the early seventies, there have been reported cases of crude oil spill in the Niger-Delta area with the release of more than two million barrels of crude oil into the environment (Akpovire, 1989; Daniel - Kalio and Pepple, 2006).

Spilled oil has negative impact on physiological and biochemical processes in organisms resulting in major risks to the environment by poisoning exposed organisms and causing serious threats to farmland and humans (Adedokun and Ataga, 2007; Daniel Kalio and Pepple, 2006).

Bean seeds (Vigna unguiculata $L$ ) are one of the commonest and cheapest food, in the Niger-Delta area of Nigeria from where most of Nigeria's crude oil is derived (Agbogidi et al., 2007). There are several vegetal species that are capable of growing in soils polluted with hydrocarbons and they participate in their degradation through the rhizosphere which favors the growth of several microorganisms. Studies have shown that some plants can tolerate crude oil pollutants in soil (Aprill and Sims, 1990; Liste and Alexander, 2000; Rentz et al., 2003). However, the ecological effects of metals depend strongly on the specific chemical forms (Gupta and Sinha, 2007; Obasi et al., 2012). In order to assess the environmental quality of the contaminated soil, the prediction of the bioavaliable concentration of the metals is more important than the total concentration of the metals since it controls bioavailability which controls metal soil-plant transfer (Ikhouria et al., 2010; Obasi et al., 2013). Uptake of metal ions by plants (phytoavailbility) has been defined through a one step soil extracting procedure. 
The use of single extractants for the prediction of bioavailability of metals from tannery sludge amended soil has been reported (Obasi, et al., 2013) but no such report on the availability of metals from crude oil contaminated soil.

The study investigated and compared the total concentration, bioavaliable concentration and EDTA- extractable metal ions in the crude oil contaminated soil and also evaluated the potential of the extractant for the prediction of bioavailability of the metals from crude oil contaminated soil to the bean seedlings.

\section{MATERIALS AND METHODS \\ SOIL SAMPLING AND PRE-TREATMENT}

Top soil $(0-20 \mathrm{~cm}$ depth) sample was collected from an uncultivated land without known crude oil contamination at Usen community in Edo State, Nigeria. Holes were dug at five different points within the land to a $20 \mathrm{~cm}$ depth each using plastic spade. Also, another soil sample was collected from Ubeji community in Delta State, Nigeria where there was crude oil spill from a Bonny light crude oil pipe line. Within, the spillage site (Ubeji), holes were dug at five different points to a depth of $20 \mathrm{~cm}$ using plastic spade and soil samples were collected into polythene bags and taken to the laboratory. A composite of all the samples was made by mixing thoroughly equal amounts of soil from each point. The soils were airdried at room temperature, crushed in a porcelain mortar and sieved through a $2 \mathrm{~mm}$ sieve. The airdried $<2 \mathrm{~mm}$ samples were stored in polythene bags and labeled for future use. The composite soil from Usen community was weighed into 60 polythene bags such that each bag contained $500 \mathrm{~g}$ soil and another 30 bags containing the soil collected from Ubeji community where there was crude oil spillage (referred to as Ubeji), making a total of 90 bags.

\section{Soil Treatment}

The 60 polythene bags containing Usen soil was shared into two groups of 30 bags each. To one group which served as control (C), crude oil was not added to the soil; instead, distilled water was used. To the other group, $50 \mathrm{ml}$ of crude oil was mixed thoroughly with $500 \mathrm{~g}$ soil in their respective polythene bags with the aid of a plastic spade. The sample was referred to as crude oil contaminated soil (CCS).

\section{Planting of Seeds}

Seed viability was assessed by floatation method. The seeds were placed in a beaker containing distilled water and stirred. The seeds that did not float were regarded as viable seeds while those that floated where regarded as non-viable and discarded. The seeds were planted by a modified version of Vavrek and Campbell (2002). Three viable bean seeds were sown in $500 \mathrm{~g}$ sandy loam soil with a depth of about $1-2 \mathrm{~cm}$ and watered daily with distilled water.

\section{Plant Analysis}

After 21days post germination, equal amounts of seedlings that germinated were harvested and washed thoroughly with running tap water, blotted dry, cut into pieces, mixed thoroughly and oven dried at $80^{\circ} \mathrm{C}$ for 2 days. $1 \mathrm{~g}$ of the oven dried samples was weighed and ashed in a muffle furnace at $500^{\circ} \mathrm{C}$ for $3 \mathrm{hrs}$. The ash was dissolved in $20 \%$ trioxonitrate (v) acid and filtered through a Whatman No. 1 filter paper and made up to $100 \mathrm{ml}$ mark. The metal contents were determined using Atomic Adsorption Spectrophotometer (AAS) Bulk Scientific (VGP210) (Gupta and Sinha, 2007).

\section{Physicochemical Analyses}

The physicochemical analysis of the soil was assayed according to methods described by A.O.A.C, (1995) using Atomic Absorption Spectrophotometer.

\section{Single Extraction of Total Metals}

EDTA extractable fraction was obtained by mechanical shaking of the sample $(5 \mathrm{~g})$ at 200rpm with $50 \mathrm{ml}$ of $0.05 \mathrm{M}$ EDTA solution at room temperature for 6hrs. For the determination of total $\mathrm{Fe}, \mathrm{Cd}, \mathrm{Pb}, \mathrm{Cu}$ and $\mathrm{Zn}$ concentrations in the soil using modified version of acid dissolution method described in Gupta and Sinha (2007), 1g of soil was digested with $5 \mathrm{ml}$ of $\mathrm{HNO}_{3}$ and $1 \mathrm{ml}$ of $\mathrm{HClO}_{4}$ in a digester for $6 \mathrm{hrs}$. The digested solution was then diluted with distilled water and filtered through a Whatman No. 1 filter paper and made up to $100 \mathrm{ml}$. The heavy metals in the solution were determined using Atomic Adsorption Spectrophotometer (AAS) Bulk Scientific (VGP210).

\section{Soil Fractionation}

Fractionation studies were performed on the soil samples to assess the amount of bioavalable metals before planting bean seeds and EDTA extraction. Uba et al. (2008) method, a modified version of Tessier et al. (1979), was used to investigate the distribution of the metals in the soils into five optional geochemical forms.

\section{Quality Control and Statistical Analysis}

All reagents used for the preparation of standard solutions and analyses were analytical grades (BDH or Sigma). Buck Scientific standard solutions (Buck scientific Inc.) were used to calibrate the Spectrophotometer. Procedural blank samples were subjected to similar extraction method using the same amounts of reagents. All experiments were done in triplicate and results expressed as mean \pm standard error of mean (SEM). Analysis of variance was used to test for differences in the groups, while Duncan's multiple comparisons test was used to determine significant differences between means.

\section{RESULTS AND DISCUSSION}

Physicochemical properties of crude oil contaminated soil (CCS) and control soils

The results of the physicochemical analyses are shown in Table 1. Results obtained showed that cation exchange capacity, total organic carbon, and total organic matter were significantly higher $(P<$ 0.05) in the crude oil contaminated soil when compared to control soil. However, $\mathrm{pH}$ was significantly lower $(P<0.05)$ in the 
Crude oil contaminated soil $(5.84 \pm 0.03)$ but higher in the Ubeji soil (6.74 \pm 0.01$)$ when compared to control soil (6.44 \pm 0.03$)$. The lower $\mathrm{pH}$ (more acidic) recorded for the CCS than those of the uncontaminated (Control) soil may be as a result of some phenol present in crude oil (CONCAWE, 2003). The relatively higher $\mathrm{pH}$ observed in Ubeji may be as a result of difference in soil location. The results generally observed a moderately acidic soil. Similar $\mathrm{pH}$ values were reported for Niger Delta soils, some soils in other parts of Nigeria and soils with cassava processing effluents (Iwegbue et al., 2013; Nwakaudu et al., 2012). However, it is at variance with $\mathrm{pH}$ values reported by Obasi et al. (2013) for dumpsites. The observed $\mathrm{pH}$ values in the soils may have altered the physicochemical properties of the soil as well as the chemical forms and the levels of uptake of metals by the bean plant (Obasi et. al., 2012). Particle size indicated mainly sandy clay loam (for C and CCS) and sandy loam for Ubeji. The high conductivity value of the crude oil contaminated soil may be attributed to the presence of metals that are soluble salts in the soil (Obasi et. al., 2012).

The higher values of cation exchange capacity (CEC) observed in CCS and Ubeji when compared with control are comparable to values of CEC reported in soil that received cassava effluents in Benin City, Nigeria (Oviasogie and Ofomaja, 2007). The high CEC in CCS and Ubeji may be due to high calcium content in the soils contaminated with crude oil. The total organic carbon (TOC) and Total Organic Matter (TOM) values obtained in the results are comparable to those reported by Obasi et. al., (2012). The levels of organic matter in soils affect the soil chemical and physical processes and acts as an indicator of the soils ability to hold plants (Obasi et. al., 2012).

Table 1: Physicochemical properties of crude oil contaminated soil (CCS), Ubeji and control soil (dry weight).

\begin{tabular}{|c|c|c|c|}
\hline Parameter/Sample & Control & CCS & UBEJI \\
\hline $\mathrm{pH}\left(\mathrm{H}_{2} \mathrm{O}\right)$ & $6.44 \pm 0.03^{a}$ & $5.84 \pm 0.14^{b}$ & $6.74 \pm 0.01^{c}$ \\
\hline Soil Texture & Sandy clay loam & Sandy clay loam & Sandy loam \\
\hline $\begin{array}{l}\text { Cation Exchange Capacity } \\
(\text { Cmol/kg) }\end{array}$ & $7.08 \pm 0.01^{a}$ & $9.05 \pm 0.07^{b}$ & $9.98 \pm 0.02^{\mathrm{e}}$ \\
\hline $\begin{array}{l}\text { Total Hydrocarbon Content } \\
\text { (THC. } \mathrm{mg} / \mathbf{k g} \text { ) }\end{array}$ & $0.00 \pm 0.01^{a}$ & $17.34 \pm 0.01^{b}$ & $74.88 \pm 0.01^{\mathrm{e}}$ \\
\hline Total Organic Carbon (\%) & $1.26 \pm 0.01^{a}$ & $3.31 \pm 0.02^{\mathrm{b}}$ & $3.89 \pm 0.01^{\mathrm{e}}$ \\
\hline Total Organic Matter (\%) & $2.17 \pm 0.02^{\mathrm{a}}$ & $5.71 \pm 0.05^{b}$ & $5.41 \pm 0.02^{\text {be }}$ \\
\hline Clay $(\%)$ & 26.68 & 28.0 & 16.28 \\
\hline Silt (\%) & 10.30 & 12.0 & 10.70 \\
\hline Sand $(\%)$ & 63.02 & 60.0 & 73.02 \\
\hline
\end{tabular}

Values are mean of three $(n=3)$ replicates \pm standard error of mean, CCS $=$ crude oil contaminated soil, UBEJI = Spill site of crude oil, THC = Total Hydrocarbon Content. Means of the same row carrying different notations are statistically different at $\mathrm{P}<0.05$ using Instat graphpad.

Levels of heavy metals in crude oil contaminated soil, Ubeji and control soil

The concentration of heavy metals in the crude oil contaminated soil, Ubeji and control soil are presented in Table 2. The values of $\mathrm{Cd}, \mathrm{Pb}, \mathrm{Fe}, \mathrm{Cu}$, and $\mathrm{Zn}$ for contaminated soil were above the value of control soil but below those of $4.7 \% \mathrm{Fe} .190 \mathrm{mg} / \mathrm{kg} \mathrm{Cu}$, $720 \mathrm{mg} / \mathrm{kg} \mathrm{Zn}, 36 \mathrm{mg} / \mathrm{kg} \mathrm{Cu}$ and $140 \mathrm{mg} / \mathrm{kg} \mathrm{Zn}$ intervention and target values for soils provided by Department of Petroleum Resources (DPR) guidelines. Other researchers also reported elevated levels of heavy metals in different types of contaminated soils (Iwegbue et. al., 2013; Obasi et. al., 2012; Okoye and Okwute, 2014). The higher concentration of metals in the CCS and Ubeji soil may be attributed to the crude oil present in the soil. The low concentrations of the metals in the control soil even though control soil and CCS are from the same source (Usen soil), confirm that crude oil was the reason for the increase. The metal with the highest mean concentration is Fe (Table 2).

Table 2: Levels of heavy metals in crude oil contaminated soil, Ubeji and control soil (mg/kg soil dry weight)

\begin{tabular}{llll}
\hline Metal/Sample & Control & CCS & UBEJI \\
\hline Cadmium (Cd) & $0.01 \pm 0.01^{\mathrm{a}}$ & $0.05 \pm 0.03^{\mathrm{a}}$ & $0.01 \pm 0.01^{\mathrm{a}}$ \\
Lead (Pb) & $0.08 \pm 0.01^{\mathrm{a}}$ & $0.84 \pm 0.23^{\mathrm{b}}$ & $5.00 \pm 0.12^{\mathrm{c}}$ \\
Zinc(Zn) & $10.00 \pm 0.03^{\mathrm{a}}$ & $46.12 \pm 0.03^{\mathrm{b}}$ & $50.00 \pm 0.04^{\mathrm{c}}$ \\
Iron (Fe) & $119.75 \pm 0.07^{\mathrm{a}}$ & $165.18 \pm 0.04^{\mathrm{b}}$ & $300.95 \pm 0.14^{\mathrm{c}}$ \\
Copper (Cu) & $1.05 \pm 0.02^{\mathrm{a}}$ & $4.60 \pm 0.02^{\mathrm{b}}$ & $6.00 \pm 0.02^{\mathrm{c}}$ \\
\hline
\end{tabular}

Values are mean of three $(n=3)$ replicates \pm standard error of mean, CCS $=$ crude oil contaminated soil, UBEJI = Spill site of crude oil, Means of the same row carrying different notations are statistically different at $P<0.05$ using Instat graphpad. 
Fractionation of $\mathrm{Cd}, \mathrm{Pb}, \mathrm{Fe}, \mathrm{Cu}$, and $\mathrm{Zn}$ in the crude oil contaminated soil before treatment The geochemical forms in which the metals were distributed in the crude oil contaminated soil before planting the bean seeds and EDTA extraction are shown in Tables $3 \mathrm{~A}$ to $3 \mathrm{E}$. The highest concentrations of $\mathrm{Cu}, \mathrm{Zn}, \mathrm{Pb}$ and $\mathrm{Fe}$ were found in the residual fractions of the crude oil contaminated soil. This may be as a result of the sandy nature of the soil as well as presence of acid resistant minerals and the coprecipitation of the metals with various silicate species consequent to their adsorption into mineral lattice (Rahman et al., 2004). Similar results were recorded by other researchers in different contaminated soils (Iwegbue et. al., 2013; Obasi et. al., 2012; Obasi et. al., 2013). Cadmium was not detected in all the fractions except the acid soluble fraction, an indication that it may be readily soluble and mobile. The percent bioavailability of the metals in the crude oil contaminated soils is relatively high since the mobile phase contains reasonable percent of total extractable fractions suggesting that the metals in CCS and Ubeji soils are potentially more bioavailable for the plant uptake (Obasi et. al., 2013).

Table 3A: Fractionation tests of $\mathrm{Cd}$ in the crude oil contaminated soil before treatment ( $\mathrm{mg} / \mathrm{kg} \mathrm{soil}$ dry weight)

\begin{tabular}{cccc}
\hline Fraction & Control & CCS & UBEJI \\
\hline Exchangeable & ND & ND & ND \\
Oxidizable & ND & ND & ND \\
Acid soluble & ND & $0.05 \pm 0.02^{\mathrm{a}}$ & $0.01 \pm 0.01^{\mathrm{b}}$ \\
Reducible & $\mathrm{ND}$ & $\mathrm{ND}$ & $\mathrm{ND}$ \\
Residual & $0.01 \pm 0.01$ & $\mathrm{ND}$ & $\mathrm{ND}$ \\
TEMs & $0.01 \pm 0.01^{\mathrm{a}}$ & $0.05 \pm 0.02^{\mathrm{b}}$ & $0.01 \pm 0.01^{\mathrm{a}}$ \\
Sum of BF & 000 & 000 & 000 \\
Residual (\%) & 100 & 0.00 & 0.00 \\
Percent Bioavailable (\%) & 0.00 & 0.00 & 0.00 \\
\hline
\end{tabular}

Values are mean of three $(n=3)$ replicates \pm standard error of mean, TEMs $=$ total extractable metals, $\mathrm{BF}=$ bioavailable fraction, $\mathrm{CCS}=$ crude oil contaminated soil, UBEJI = Soil from Crude oil spill, ND $=$ Not Detectable., Means of the same row carrying different notations are statistically different at $\mathrm{P}<0.05$ using Instat graphpad

Table 3B: Fractionation tests of Pb before treatment ( $\mathrm{mg} / \mathrm{kg}$ soil dry weight)

\begin{tabular}{cccc}
\hline Fraction & Control & CCS & UBEJI \\
\hline Exchangeable & ND & $0.37 \pm 0.02^{\mathrm{a}}$ & $1.34 \pm 0.03^{\mathrm{b}}$ \\
Oxidizable & $\mathrm{ND}$ & $\mathrm{ND}$ & $\mathrm{ND}$ \\
Acid soluble & $\mathrm{ND}$ & $0.19 \pm 0.02^{\mathrm{a}}$ & $1.00 \pm 0.05^{\mathrm{b}}$ \\
Reducible & $\mathrm{ND}$ & $\mathrm{ND}$ & $0.24 \pm 0.02^{\mathrm{a}}$ \\
Residual & $\mathrm{ND}$ & $0.31 \pm 0.02^{\mathrm{a}}$ & $1.58 \pm 0.03^{\mathrm{b}}$ \\
TEMs & 0.00 & $0.84 \pm 0.05^{\mathrm{a}}$ & $4.16 \pm 0.11^{\mathrm{b}}$ \\
Sum of BF & 0.00 & 0.56 & 2.34 \\
Residual (\%) & 0.00 & 36.79 & 37.98 \\
Percent Bioavailable (\%) & 0.00 & 67 & 47 \\
\hline
\end{tabular}

Values are mean of three $(n=3)$ replicates \pm standard error of mean, TEMs $=$ total extractable metals, BF = bioavailable fraction, $\mathrm{CCS}=$ crude oil contaminated soil, UBEJI = Soil from Crude oil spill, ND = Not Detectable., Means of the same row carrying different notations are statistically different at $\mathrm{P}<0.05$ using Instat graphpad

Table 3C: Fractionation tests of $\mathrm{Zn}$ before treatment ( $\mathrm{mg} / \mathrm{kg}$ soil dry weight)

\begin{tabular}{cccc}
\hline Fraction & Control & CCS & UBEJI \\
\hline Exchangeable & $0.28 \pm 0.01^{\mathrm{a}}$ & $3.14 \pm 0.02^{\mathrm{b}}$ & $8.85 \pm 0.03^{\mathrm{c}}$ \\
Oxidizable & $03.38 \pm 0.06^{\mathrm{a}}$ & $10.70 \pm 0.02^{\mathrm{b}}$ & $10.11 \pm 0.03^{\mathrm{c}}$ \\
Acid soluble & $0.68 \pm 0.06^{\mathrm{a}}$ & $8.92 \pm 0.02^{\mathrm{b}}$ & $7.75 \pm 0.03^{\mathrm{c}}$ \\
Reducible & $03.35 \pm 0.03^{\mathrm{a}}$ & $6.50 \pm 0.02^{\mathrm{b}}$ & $9.08 \pm 0.05^{\mathrm{c}}$ \\
Residual & $1.36 \pm 0.03^{\mathrm{a}}$ & $14.08 \pm 0.02^{\mathrm{b}}$ & $15.28 \pm 0.03^{\mathrm{c}}$ \\
TEMs & $09.05 \pm 0.07^{\mathrm{a}}$ & $43.34 \pm 0.23^{\mathrm{b}}$ & $51.07 \pm 0.06^{\mathrm{c}}$ \\
Sum of BF & 0.96 & 12.06 & 16.60 \\
Residual (\%) & 15.03 & 32.48 & 29.92 \\
Percent Bioavailable (\%) & 10 & 26 & 33
\end{tabular}

Values are mean of three $(n=3)$ replicates \pm standard error of mean, TEMs = total extractable metals, BF = bioavailable fraction, $\mathrm{CCS}=$ crude oil contaminated soil, UBEJI = Soil from Crude oil spill, ND = Not
Detectable., Means of the same row carrying different notations are statistically different at $\mathrm{P}<0.05$ using Instat graphpad 
Table 3D: Fractionation tests of Fe before treatment ( $\mathrm{mg} / \mathrm{kg}$ soil dry weight)

\begin{tabular}{cccc}
\hline Fraction & Control & CCS & UBEJI \\
\hline Exchangeable & $19.18 \pm 0.01^{\mathrm{a}}$ & $43.14 \pm 0.02^{\mathrm{b}}$ & $20.80 \pm 0.07^{\mathrm{c}}$ \\
Oxidizable & $25.20 \pm 0.06^{\mathrm{a}}$ & $13.70 \pm 0.02^{\mathrm{b}}$ & $92.39 \pm 0.05^{\mathrm{c}}$ \\
Acid soluble & $16.68 \pm 0.06^{\mathrm{a}}$ & $0.10 \pm 0.02^{\mathrm{b}}$ & $46.90 \pm 0.03^{\mathrm{c}}$ \\
Reducible & $24.17 \pm 0.06^{\mathrm{a}}$ & $35.50 \pm 0.02^{\mathrm{b}}$ & $16.35 \pm 0.03^{\mathrm{c}}$ \\
Residual & $30.35 \pm 0.03^{\mathrm{a}}$ & $65.86 \pm 0.02^{\mathrm{b}}$ & $122.43 \pm 0.03^{\mathrm{c}}$ \\
TEMs & $115.58 \pm 0.07^{\mathrm{a}}$ & $158.30 \pm 0.03^{\mathrm{b}}$ & $298.87 \pm 0.02^{\mathrm{c}}$ \\
Sum of BF & 35.86 & 43.24 & 67.70 \\
Residual (\%) & 26.26 & 41.61 & 40.96 \\
Percent Bioavailable (\%) & 30 & 26 & 22 \\
\hline
\end{tabular}

Values are mean of three $(n=3)$ replicates \pm standard error of mean, TEMs $=$ total extractable metals, $\mathrm{BF}=$ bioavailable fraction, $\mathrm{CCS}=$ crude oil contaminated soil, UBEJI = Soil from Crude oil spill, ND = Not
Detectable., Means of the same row carrying different notations are statistically different at $\mathrm{P}<0.05$ using Instat graphpad

Table 3E: Fractionation tests of $\mathrm{Cu}$ before treatment ( $\mathrm{mg} / \mathrm{kg}$ soil dry weight)

\begin{tabular}{cccc}
\hline Fraction & Control & CCS & UBEJI \\
\hline Exchangeable & ND & $0.50 \pm 0.02^{\mathrm{a}}$ & $1.89 \pm 0.03^{\mathrm{b}}$ \\
Oxidizable & $0.05 \pm 0.03$ & $\mathrm{ND}$ & $\mathrm{ND}$ \\
Acid soluble & $\mathrm{ND}$ & $\mathrm{ND}$ & $\mathrm{ND}$ \\
Reducible & $0.04 \pm 0.03^{\mathrm{a}}$ & $0.93 \pm 0.05^{\mathrm{b}}$ & $\mathrm{ND}$ \\
Residual & $0.08 \pm 0.03^{\mathrm{a}}$ & $2.86 \pm 0.02^{\mathrm{b}}$ & $4.11 \pm 0.03^{\mathrm{c}}$ \\
TEMs & $0.17 \pm 0.07^{\mathrm{a}}$ & $4.29 \pm 0.14^{\mathrm{b}}$ & $6.00 \pm 0.05^{\mathrm{c}}$ \\
Sum of BF & 0 & 0.50 & 1.89 \\
Residual (\%) & 47.06 & 67.14 & 68.50 \\
Percent Bioavailable (\%) & 0 & 11 & 32 \\
\hline
\end{tabular}

Values are mean of three $(n=3)$ replicates \pm standard error of mean, CCS $=$ crude oil contaminated soil, UBEJI = Soil from Crude oil spill, ND = Not

Concentration of metals in bean seedlings 21 days post germination and concentration of EDTA extractable metals after 6hrs EDTA extraction in CCS ( $\mathrm{mg} / \mathrm{kg}$ soil dry weight)

The results of the concentration of metals accumulated in the bean seedlings 21 days post germination, concentrations extracted by EDTA and the residual concentration of the metals in the crude oil contaminated soil is given in Tables $4 \mathrm{~A}$ and $4 \mathrm{~B}$.

The metals analysed in the bean seedlings recorded higher concentrations in CCS and Ubeji soil than in the control soil but Cd was not detectable in all the fractions. The mean concentrations of the metals taken up by the bean seedlings 21 days post
Detectable., Means of the same row carrying different notations are statistically different at $\mathrm{P}<0.05$ using Instat graphpad

germination ranged from $0.10-0.27 \mathrm{mg} / \mathrm{kg} \mathrm{Pb}, 7.27-$ $10.29 \mathrm{mg} / \mathrm{kg} \mathrm{Zn}, 43.60-60 \mathrm{mg} / \mathrm{kg} \mathrm{Fe}$ and $0.90-$ $1.43 \mathrm{mg} / \mathrm{kg} \mathrm{Cu}$ in the CCS and Ubeji soil. The uptake of $\mathrm{Fe}$ by the bean seedlings was the highest. The sandy nature of the soil may have contributed to Fe mobility and uptake by the plant. Similar results on the uptake of heavy metals have been reported for various plant species by other researchers (Obasi et. al., 2013; Okoye and Okwute, 2014). When the concentration of metals removed by the bean seedlings and EDTA were compared, it was observed that EDTA removed more metal from the crude oil contaminated soil than the bean seedlings.

Table 4A: Concentration of metals in bean seedlings 21 days post germination and EDTA extractable concentrations in CCS after $6 \mathrm{hrs}$ EDTA extraction ( $\mathrm{mg} / \mathrm{kg}$ soil dry weight)

\begin{tabular}{|c|c|c|c|c|c|}
\hline Samples/Metals & $\mathrm{Cd}(\mathrm{mg} / \mathrm{kg})$ & $\mathrm{Pb}(\mathrm{mg} / \mathrm{kg})$ & $\mathrm{Zn}(\mathrm{mg} / \mathrm{kg})$ & $\mathrm{Fe}(\mathrm{mg} / \mathbf{k g})$ & $\mathrm{Cu}(\mathrm{mg} / \mathrm{kg})$ \\
\hline Bean seedlings & ND & $0.10 \pm 0.03$ & $10.29 \pm 0.06$ & $60.00 \pm 0.03$ & $0.92 \pm 0.02$ \\
\hline $\begin{array}{l}\text { EDTA extractable } \\
\text { concentrations }\end{array}$ & ND & $0.63 \pm 0.01$ & $30.17 \pm 0.01$ & $146.18 \pm 0.01$ & $3.26 \pm 0.01$ \\
\hline Soil after germination & ND & $0.08 \pm 0.02$ & $35.41 \pm 0.02$ & $105.18 \pm 0.02$ & $1.34 \pm 0.02$ \\
\hline Soil after EDTA extraction & ND & $0.21 \pm 0.01$ & $15.95 \pm 0.01$ & $19.00 \pm 0.01$ & $1.34 \pm 0.01$ \\
\hline $\begin{array}{l}\% \text { removal } \\
\text { (by bean seedlings) }\end{array}$ & NA & 12 & 22 & 36 & 20 \\
\hline $\begin{array}{l}\text { \% removal } \\
\text { (by EDTA) }\end{array}$ & NA & 75 & 65 & 88 & 71 \\
\hline
\end{tabular}

Values are mean of three $(n=3)$ replicates \pm standard error of mean, CCS $=$ crude oil contaminated soil, NA $=$ Not applicable, ND $=$ Not Detectable., Means of the same row carrying different notations are statistically different at $P<0.05$ using Instat graphpad 
Table 4B: Concentration of metals in bean seedlings after 21 days post germination and EDTA extractable concentrations after 6 hrs EDTA extraction in Ubeji soil

\begin{tabular}{|c|c|c|c|c|c|}
\hline Samples/Metals & Cd $(\mathrm{mg} / \mathrm{kg})$ & $\mathrm{Pb}(\mathrm{mg} / \mathbf{k g})$ & Zn (mg/kg) & $\mathrm{Fe}(\mathrm{mg} / \mathrm{kg})$ & $\mathrm{Cu}(\mathrm{mg} / \mathrm{kg})$ \\
\hline Bean seedlings & ND & $0.27 \pm 0.01$ & $7.27 \pm 0.05$ & $43.60 \pm 0.02$ & $1.43 \pm 0.02$ \\
\hline $\begin{array}{l}\text { EDTA extractable } \\
\text { concentrations }\end{array}$ & ND & $3.74 \pm 0.03$ & $39.48 \pm 0.03$ & $274.05 \pm 0.07$ & $4.39 \pm 0.02$ \\
\hline Soil after germination & ND & $0.15 \pm 0.01$ & $37.44 \pm 0.02$ & $257.40 \pm 0.05$ & $2.74 \pm 0.02$ \\
\hline $\begin{array}{l}\text { Soil after EDTA } \\
\text { extraction }\end{array}$ & ND & $1.26 \pm 0.01$ & $10.52 \pm 0.01$ & $26.90 \pm 0.04$ & $1.61 \pm 0.01$ \\
\hline $\begin{array}{l}\% \text { removal } \\
\text { (by bean seedlings) }\end{array}$ & NA & 5 & 15 & 14 & 24 \\
\hline $\begin{array}{l}\% \text { removal } \\
\text { (by EDTA) }\end{array}$ & NA & 75 & 79 & 91 & 73 \\
\hline
\end{tabular}

Values are mean of three $(n=3)$ replicates \pm standard error of mean, CCS $=$ crude oil contaminated soil, $N A=$ Not applicable, ND = Not Detectable., Means of the same row carrying different notations are statistically different at $\mathrm{P}<0.05$ using Instat graphpad

\section{Comparison of the concentration of metals in CCS and Ubeji soil using several techniques}

It was observed when comparing concentrations of $\mathrm{Cu}, \mathrm{Zn}, \mathrm{Pb}$ and Fe obtained using several techniques that the least concentration of $\mathrm{Pb}$ and $\mathrm{Cu}$ were found in harvested beans seedlings when compared to their concentration in the total metals. The highest concentrations of the metals were extracted by EDTA. The concentration of $\mathrm{Fe}$ accumulated in the bean seedling was higher than the bioavailable concentration in the CCS before germination. Lead was the least metal concentrated by bean seedling in the CCS.

\section{CONCLUSION}

The study predicts the effectiveness of EDTA in chemical forms and availability of $\mathrm{Cd}, \mathrm{Pb}, \mathrm{Zn}, \mathrm{Fe}$ and

\section{REFERENCES}

Adedokun, O. M. and Ataga, A. E. (2007): Effects of Amendments and Bioaugumentation of Soil Polluted with Crude Oil, Automotive Gasoline Oil, And Spent Engine Oil on the Growth of Cowpea (Vigna nguiculata L. Walp). Scientific Research and Essay, (5):197-149.

Agbogidi, O. M., Eruotor, P. G. and Akparobi, S. O. (2007): Effects of Crude Oil Levels on the Growth of Maize (Zea mays L.). American Journal of Food Technology, 2: 529-535.

Akpovire, B. O. (1989): Education against Environmental Pollution in Nigeria. Convergence, 22(4): $55-60$.

Albers, P. H. (1995): Petroleum and Individual Polycyclic Aromatic Hydrocarbons. In: Hoffman, D.J., Rattner, B.A., Burton, C.A., Cairns, J. (Eds). Handbook of Ecotoxicology, Lewis Publishers, Boca Raton. $330-355$.

Amund, O. O. and Akangou, T. S. (1993): Microbial Degradation of Four Nigerian Crude Oils in an Estuarine Microcosm. Letters of Applied Microbiology, 16: $118-121$.

A.O.A.C. (1995): Official Methods of Analysis. Association of Official Analytical Chemists,
$\mathrm{Cu}$. The study also indicated that the concentration of the metals taken up by bean seedlings was lower than the bioavailable concentration but the concentration extractable by EDTA was higher than the bioavailable concentrations.

\section{ACKNOWLEDGMENTS}

We are grateful to the laboratory staff of the Department of Biochemistry, Faculty of Life Sciences, University of Benin, Benin City, Department of Science Laboratory and Technology, School of Applied Sciences, Edo State Institute of Technology and Management, Usen, Edo State and School of Agriculture, Federal University of Technology, Akure, Ondo State, Nigeria.

$15^{\text {th }}$ ed., Arlington, V. A. Methods 992.006 to 962.09.

Aprill, W. and Sims, R. (1990): Evaluation of the Use of Prairie Grasses for Stimulating Polycyclic Aromatic Hydrocarbon Treatment in Soil. Chemosphere, 20: 253-265.

Daniel - Kalio, L. A and Pepple, S. F. (2006): Effect of Bonny Light Crude Oil Pollution of Soil on the Growth of Dayflower (Commelina benghalensis L.) in the Niger Delta, Nigeria. Journal of Applied Sciences, 10 (2): $111-114$.

DPR (Department of petroleum resources) (2002): Environmental guidelines and standards for the petroleum industry in Nigeria (revised edition). Department of Petroleum Resources,Ministry of Petroleum and Natural Resources, Abuja, Nigeria.

Gupta, A. K. and Sinha, S. (2007): Assessment of Single Extraction Methods for the Prediction of Bioavailability of Metals to Brassica juncea L Czean (var. Vaibhav) grown on tannery waste contaminated soil. Journal of hazardous Materials, 149 (2): 141-150. 
Ikhouria, E. U., Urunmatsoma, S. O. P. and Okieimen, F. E. (2010): Preliminary Investigation of Chemical Fraction and Heavy Metal Accumulation in Plant Maize (Zea mays) Grown on Chromated Copper Arsenate (CCA) Contaminated Soil Amended with Poultry Droppings.African Journal of Biotechnology, 9: 2675- 2682.

Ikhuoria, E. U. and Uyammadu, C. (2000): Adsorption of Heavy Metals on Modified Snail (Archachatina marginata) Shell. Ghana Journal of Science, 41: 28-33.

Iwegbue, C. M. A., Bassey, F. I., Tesi, G. O., Nwajei, G. E and Tsafe, A. I. (2013): Assessment of Heavy Metal Contamination in Soils around Cassava Processing Mills in SubUrban Areas of Delta State, Southern Nigeria. Nigerian Journal of Basic and Applied Sciencs, 21(2): 96-104

Liste, H. H. and Alexander, M. (2000): PlantPromoted Pyrene Degradation in Soil. Chemosphere, 40: 7-10.

Nwakaudu, M. S., Kamen, F. L., Afube, G., and Nwakaudu, A. A. and Ike, I. S. (2012): Impact

of Cassava Processing Effluent on Agricultural Soil: A Case Study of Maize Growth. Journal of Emerging Trends in Engineering and Applied Sciences, 3(5): 881-885

Ntiforo, A., Anim-Gyampo, M. and Nyame, F. K. (2012): Heavy Metal Concentration in Drinking Water Sources Affected by Dredge Mine Operations of a Gold Mining Company in Ghana. Research Journal of Environment and Earth Science, 4(6): 633639.

Obasi, N. A., Akubugwo, E. I., Kalu, K. M., Ugbogu, A. E. and Okorie, U. C. (2013): Toxicological assessment of various metals on selected edible leafy plants of Umuka and Ubahu dumpsites in Okigwe of Imo State, Nigeria. Journal of Experimental Biology and Agricultural Sciences, 1(6): 441-453

Obasi, N. A., Akubugwo, E. I., Ugbogu, O. C. and Otuchristian, G. (2012): Assessment of Physico-chemical Properties and Heavy Metals Bioavailability in Dumpsites along Enugu-port Harcourt Expressways, Southeast, Nigeria. Asian Journal of Applied Sciences, 5: 342-356.
Okoye, C. O. and Okwute, G. A. (2014): Heavy Metal Concentrations In Food Crops Grown In Crude Oil Impacted Soils in Olomoro, Delta State-Nigeria and Their Health Implications.

International Journal of Engineering Science Invention, 3, (31) 15-21.

Pourrut, B., Shahid, M., Dumat, C., Winterton, P. and Pinelli, E. (2011): Lead uptake, toxicity, and detoxification in plants. Reviews of Contamination and Toxicology, 213:113136.

Rahman, F. R., Allan, D. L., Rosen, C. J. and Sadowky, M. J. (2004). Arsenic Availability from Chromate Copper Arsenate (CCA) Treated Wood. Journal of Environmental Quality, 33:173-180.

Rentz, J. A., Chapman, B., Alvarez, P. J. and Schnoor, J. L. (2003): Stimulation of Hybrid Poplar Growth in Petroleum-Contaminated Soils through Oxygen Addition and Soil Nutrient Amendments. International Journal of Phytoremediation, 5: 57-72.

Sarkodie, P. A., Nyamah, D. and Amonoo-Neizer, E. H. (1997): Speciation of Arsenic in some Biological Samples from Obuasi and its Surrounding villages, UST-IDRC, 97: National

Symposium Proceedings, pp: 147-154.

Sparks, D. L. (2003): Environmental Soil Chemistry. $3^{\text {rd }}$ edn. Academic Press.

Tessier, A., Campbell, P. G. C. and Bissom, M. (1979): Sequential extraction procedure for the speciation of particulate trace metals. Analytical Chemistry, 51 (7): 844-851.

Uba, S., Uzairu, A., Harrison, G. F. S., Balarabe, M. L. and Okunola, O. J. (2008): Assessment of Heavy Metals Bioavailability in Dumpsites of Zaira Metropolis, Nigeria. African Journal of Biotechnology, 7: 122-130.

Vavrek, M. C. and Campbell, W. J. (2002): Identification of Plant Traits that Enhance Biodegradation of Oil; Available:http://ipec.utulsa.edu/Ipec/conf/ 2002/vavrek campbell 20.pdf.

Wu, C. and Zhang, L. (2010): Heavy Metal Concentrations and Their Possible Sources in Paddy Soils of a Modern Agricultural Zone, South Eastern China. Environmental Earth Science, 60: 45-56. 